\title{
Knowledge, attitude and preventive practices of sexually transmitted infections among unmarried youths in an urban community in Lagos State, Nigeria
}

\begin{tabular}{|c|c|}
\hline \multicolumn{2}{|c|}{ 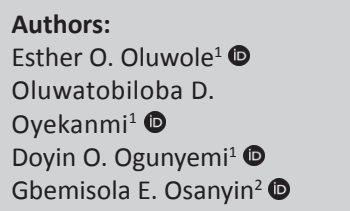 } \\
\hline \multicolumn{2}{|c|}{$\begin{array}{l}\text { Affiliations: } \\
{ }^{1} \text { Department of Community } \\
\text { Health and Primary Care, } \\
\text { College of Medicine, } \\
\text { Faculty of Clinical Sciences, } \\
\text { University of Lagos, } \\
\text { Lagos, Nigeria }\end{array}$} \\
\hline \multicolumn{2}{|c|}{$\begin{array}{l}{ }^{2} \text { Department of Obstetrics } \\
\text { and Gynaecology, College of } \\
\text { Medicine, Faculty of Clinical } \\
\text { Sciences, University of Lagos, } \\
\text { Lagos, Nigeria }\end{array}$} \\
\hline \multicolumn{2}{|c|}{$\begin{array}{l}\text { Corresponding author: } \\
\text { Esther Oluwole, } \\
\text { oluester2005@yahoo.com }\end{array}$} \\
\hline \multicolumn{2}{|c|}{$\begin{array}{l}\text { Dates: } \\
\text { Received: } 11 \text { Aug. } 2019 \\
\text { Accepted: } 31 \text { Jan. } 2020 \\
\text { Published: } 21 \text { Apr. } 2020\end{array}$} \\
\hline \multicolumn{2}{|c|}{$\begin{array}{l}\text { How to cite this article: } \\
\text { Oluwole EO, Oyekanmi OD, } \\
\text { Ogunyemi DO, Osanyin GE. } \\
\text { Knowledge, attitude and } \\
\text { preventive practices of } \\
\text { sexually transmitted } \\
\text { infections among unmarried } \\
\text { youths in an urban } \\
\text { community in Lagos State, } \\
\text { Nigeria. Afr J Prm Health Care } \\
\text { Fam Med. 2020;12(1), a2221. } \\
\text { https://doi.org/10.4102/ } \\
\text { phcfm.v12i1.2221 }\end{array}$} \\
\hline \multicolumn{2}{|c|}{$\begin{array}{l}\text { Copyright: } \\
\text { (c) 2020. The Authors. } \\
\text { Licensee: AOSIS. This work } \\
\text { is licensed under the } \\
\text { Creative Commons } \\
\text { Attribution License. }\end{array}$} \\
\hline \multicolumn{2}{|l|}{ Read online: } \\
\hline 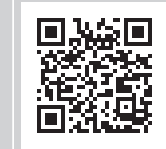 & $\begin{array}{l}\text { Scan this QR } \\
\text { code with your } \\
\text { Smart phone or } \\
\text { mobile device } \\
\text { to read online. }\end{array}$ \\
\hline
\end{tabular}

\section{Authors:}

Oluwatobiloba D.

Oyekanmi ${ }^{1}$

Doyin O. Ogunyemi ${ }^{1}$

Affiliations:

${ }^{1}$ Department of Community Coalth and Primary Care,

niversity of Lagos,

${ }^{2}$ Department of Obstetrics and Gynaecology, College of Medicine, Faculty of Clinical Sciences, University of Lagos,

Corresponding author:

Esther Oluwole,

Dates:

Accepted: 31 Jan. 2020 Ogunyemi DO, Osanyin GE. Knowledge, attitude and infections among unmarried uths in an urba Nigeria. Afr J Prm Health Care Fam Med. 2020:12(1), a2221. https://doi.org/10.4102/

Copyright:

(C) 2020. The Authors. Licensee: AOSIS. This work Creative Commons
Background: Sexually transmitted infections (STIs) are of public health importance as over 1 million STIs are acquired daily worldwide. One-third of the new cases of curable STIs affect younger persons aged less than 25 years. Sexually transmitted infections can lead to severe complications beyond the immediate impact of infections as such.

Aim: This study assessed knowledge of, attitude towards and preventive practices of STI among young unmarried persons in Surulere local government area (LGA) of Lagos State, Nigeria.

Setting: The study was conducted among young unmarried persons in Surulere LGA, Lagos State, Nigeria, between June and November 2018.

Methods: A descriptive cross-sectional study was conducted among 450 young unmarried persons selected using a multistage sampling technique. An interviewer-administered questionnaire was used to obtain data. Analysis was carried out with Epi-Info 7.2.2.2 software. Chi-square was used to test for associations. Level of significance was at $p \leq 0.05$.

Results: The mean age was $19.9+2.5$ years. Majority of the respondents $(84.7 \%)$ had heard of STIs. About two-third (65.6\%) had good knowledge, while majority $(98.6 \%)$ had good attitude towards the prevention of STIs, but less than half $(34.0 \%)$ had good preventive practices. Knowledge of STI was statistically significantly associated with age, level of education, attitude and preventive practices of the respondents.

Conclusion: Most of the respondents were aware and had good attitude towards prevention of STI, but gaps exist in knowledge and preventive practices. Hence, targeted education to improve the knowledge and preventive practices against STI among young unmarried persons is recommended.

Keywords: sexually transmitted infections; knowledge; attitude; preventive practices; unmarried youths; community survey.

\section{Introduction}

Worldwide, over a million people acquire a sexually transmitted infection (STI) daily. Every year, there is an estimated 357 million new infections with one of the four STIs globally: chlamydia (131 million), gonorrhoea (78 million), syphilis (5.6 million) or trichomoniasis (143 million). ${ }^{1}$ The United Nations, defines youths as those persons aged between 15 and 24 years. ${ }^{2}$ Young persons (youths) are those in the transition period, from the dependent phase of childhood to the interdependence of adulthood. ${ }^{3}$ Sexually transmitted infections are common among young people, with approximately 20 million new cases of STIs being reported every year in the United States, of which the majority occur among people aged between 15 and 24 years. ${ }^{4}$

Young people are at high risk of getting an STI for the following reasons: young women's bodies are biologically more prone to sexually transmitted diseases (STDs), lack of access to healthcare, confidentiality concerns and multiple sexual partners, among others. ${ }^{4}$ The Nigerian National Demographic Health Survey (NDHS) in 2008 reported that $16 \%$ of young women and $6 \%$ of young men aged between 15 and 24 years had sexual debut before the age of 15 years. A survey in Nigeria on the prevalence and predictors of early sexual debut among adolescents reported that an average of $18.6 \%$ had sexual debut before their 15 th birthday $-16.6 \%$ in boys and $20.2 \%$ in 
girls. ${ }^{5}$ This is clearly one of the reasons for the high prevalence of STIs among young people. ${ }^{6}$

Sexually transmitted infections can lead to severe complications beyond the immediate impact of infections. Some STIs, such as herpes and syphilis, can increase the risk of human immunodeficiency virus (HIV) acquisition threefold or more. Gonorrhoea and chlamydia are major causes of pelvic inflammatory disease (PID) and infertility in women. ${ }^{1}$ Data on the incidence and prevalence of STIs in Nigeria are limited because of the under-reporting of STIs, especially among young persons, which is attributable to inadequate diagnostic facilities and limited access to treatment facilities, asymptomatic episodes of the infections and the stigma associated with STI. ${ }^{7}$

Young adults are also exposed to diverse sources of influence (multiple sexual partners, lack of condom use) transecting different levels of causation. ${ }^{2}$ The knowledge of the non-HIV causes of STDs is still lacking, and the risky behaviour practiced by sexually active young adults is on the rise. Prevention of STIs includes counselling, behavioural interventions, comprehensive sexuality education, STI and HIV pre- and post-test counselling, condom promotion and interventions targeted at key populations. ${ }^{1}$ The prevention of STIs, especially in the regions where they are endemic, propelled mainly by heterosexual transmission, includes vaccination (for vaccine-preventable diseases) and practice of the 'ABC' approach (abstinence, be faithful to one partner and use of condom). ${ }^{8}$

Literature on the knowledge and preventive practices of STIs in Lagos State is quite scanty, if any at all, especially in Surulere local government area (LGA), which is one of the highly sociable urban areas, with numerous bars, clubs, lounges, malls and pubs, highly populated by young persons. Hence, this study was conducted in Surulere LGA in Lagos State to determine the knowledge of, attitude towards and preventive practices adopted by young unmarried persons against STIs.

\section{Materials and methods \\ Background information to the study area}

Lagos State is located in southwestern Nigeria with an estimated population of 21 million as of 2015. Surulere LGA is one of the 20 LGAs in Lagos, a residential and commercial LGA located on the mainland in Lagos State, Nigeria, with a total land mass of $27.1 \mathrm{~km}^{2}$. In the last census of the year 2006, there were 503975 inhabitants, with a population density of 21864 inhabitants per square kilometre, split across different age groups: 0-14 years, $29.3 \%$; $15-64$ years, $67.8 \%$; and $65+$ years, $2.9 \% .{ }^{9,10,11}$

\section{Study population, design, sample size determination and selection of participants}

The study population consisted of young unmarried youths who must have spent at least 6 months in the selected communities in the LGA. The study was a community-based, descriptive, cross-sectional study. The Cochrane's formula for descriptive study, $n=z^{2} p q / d^{2}$, was used, with a standard normal deviation at $95 \%$ confidence interval (1.96), a prevalence rate of $62.5 \%$ (0.625) from a similar study carried out in Enugu, South East Nigeria, ${ }^{12}$ and an error of precision at $5 \%(0.05)$. The minimum sample size was 360 . An additional $20 \%$ of this (72) was added to allow for possible data loss. Hence, 450 respondents were used for the study. A multi-stage probability sampling technique was used to select the respondents from the study population in five stages. Stage 1 comprised the selection of five wards of the nine wards in Surulere LGA by simple random sampling using the ballot method. In stage 2, 20\% of the total number of streets in each of the selected wards was selected through simple random sampling by ballot. Selection of houses was done via systematic sampling, with the sampling interval $(k)$ being the total number of houses on the street divided by the number of required houses in stage 3 . In stage 4 , one household was selected from each of the selected houses, while stage 5 consisted of the selection of one respondent from each household by simple random sampling using the ballot method.

\section{Study instrument and data collection}

A pretested, interviewer-administered, semi-structured questionnaire adapted from the reviewed literature ${ }^{12,13,14,15,16}$ was used for data collection. The questionnaire consisted of four sections: Section A consisted of questions on socio-demographic characteristics of the respondents, while Section B had questions on the knowledge of the respondents about STIs. Section C had Likert-scale questions assessing attitudes of the respondents towards STIs, and Section D comprised questions were asked to determine the preventive practices of the respondents against STIs.

\section{Data analyses}

Data analysis was performed using Epi-info 7.2.2.2. Results were represented in frequencies and percentages. Chi-square test was used to test for associations with the level of significance set at $p \leq 0.05$.

For the level of knowledge of each respondent about STI, every correct answer attracted one point, while every incorrect answer or non-response attracted a zero. The scores were converted to percentages and graded as poor $(<50 \%)$ and good $(\geq 50 \%)$. For attitude questions on Likert scale, the mean score was calculated. Scores below the mean were classified as poor, while those above the mean were classified as good attitudes. In assessing the preventive practices against STIs, every correct answer scored one point, while an incorrect answer or non-response scored zero. The total score for each respondent was converted to percentage and graded as poor preventive practices if $<50 \%$, and good preventive practices if $>50 \%$. 


\section{Ethical consideration}

Ethical approval for this study was obtained from the Health Research and Ethics Committee (HREC) of the Lagos University Teaching Hospital (ADM/DCST/HREC/ APP/410). Written informed consent was obtained from each respondent, with assurance of confidentiality of information and their right to withdraw from the study at any point in time. The participants were informed that participation in the study was voluntary.

\section{Results}

\section{Socio-demographic characteristics of respondents}

A total of 425 out of 450 questionnaires administered, which were adequately answered, were analysed with a response rate of $94.4 \%$. The age range and mean age \pm standard deviation (s.d.) of the respondents were 15-24 and $19.9 \pm 2.5$ years, respectively. Most $(75.8 \%)$ of the respondents were Christians of Yoruba ethnicity (68.0\%), and $64.0 \%$ had tertiary-level education (Table 1). Majority $(84.7 \%)$ of the respondents were aware of STI, and most of them $(76.7 \%)$ got information about STI from the Internet; teachers and schools (76.1\%); and electronic media (68.1\%).

\section{Knowledge of respondents about sexually transmitted infections}

Viruses (68.3\%) and bacteria (48.6\%) were the most common known causes of STIs among the respondents. Majority of the respondents $(85.8 \%)$ knew that HIV or acquired immunodeficiency syndrome (AIDS) is a type of STI; however, a few believed that diarrhoea $(23.9 \%)$, sickle cell disease (26.7\%), tuberculosis (25.4\%) and malaria (18.3\%) were examples of STIs. Majority (97.8\%) of the respondents rightly

TABLE 1: Socio-demographic characteristics of respondents.

\begin{tabular}{lcc}
\hline Socio-demographic & Frequency $(\boldsymbol{n}=\mathbf{4 2 5})$ & $\mathbf{\%}$ \\
\hline Age (years) & 179 & 42.1 \\
$15-19$ & 246 & 57.9 \\
$20-24$ & $19.9 \pm 2.5$ & - \\
Mean age (years) & & \\
Sex & 210 & 49.4 \\
Male & 215 & 50.6 \\
Female & & \\
Religion & 322 & 75.8 \\
Christianity & 99 & 23.3 \\
Islam & 2 & 0.5 \\
Traditional & 2 & 0.5 \\
Others & & \\
Tribe ethnic group & 289 & 68.0 \\
Yoruba & 97 & 22.8 \\
Igbo & 8 & 1.9 \\
Hausa & 31 & 7.3 \\
Others & & \\
Level of education & 1 & 0.2 \\
No formal education & 11 & 2.6 \\
Primary & 272 & 33.1 \\
Secondary & & 64.0 \\
Tertiary & &
\end{tabular}

knew that STIs did not have any gender predilection, as it can affect both men and women, and $96.7 \%$ knew that STIs were commonly transmitted by unprotected sexual intercourse. More than half $(61.9 \%)$ of the respondents also recognised blood transfusion as a means of STI transmission; however, less than half (46.9\%) of the respondents identified 'mother to child' route as a means of STI transmission (Table 2).

More than half $(58.1 \%)$ of the respondents knew that it is possible to be infected with no clinical symptoms. Pain on urination $(84.2 \%)$ was the commonest STI symptom, while

TABLE 2: Respondents' awareness, knowledge of causes, types and transmission of sexually transmitted infections.

\begin{tabular}{|c|c|c|}
\hline Variable & Frequency & $\%$ \\
\hline \multicolumn{3}{|l|}{ Aware of STI $(n=425)$} \\
\hline Yes & 360 & 84.7 \\
\hline No & 65 & 15.3 \\
\hline \multicolumn{3}{|l|}{ Source of information $(n=360)^{*}$} \\
\hline Electronic media & 245 & 68.1 \\
\hline Print media & 180 & 50.0 \\
\hline Public talks or seminars & 210 & 58.3 \\
\hline Internet & 276 & 76.7 \\
\hline Billboard or posters & 124 & 34.4 \\
\hline Church or mosque & 123 & 34.2 \\
\hline Hospitals or health workers & 189 & 52.5 \\
\hline Teachers or schools & 274 & 76.1 \\
\hline Friends or relations & 200 & 55.6 \\
\hline \multicolumn{3}{|l|}{ Causes of STIs* } \\
\hline Bacteria & 175 & 48.6 \\
\hline Virus & 246 & 68.3 \\
\hline Fungi & 157 & 43.6 \\
\hline Bad hygiene of the man & 142 & 39.4 \\
\hline Bad hygiene of the woman & 138 & 38.3 \\
\hline Drinking unclean water & 83 & 23.1 \\
\hline Having sex during menses & 168 & 46.7 \\
\hline Mosquitoes & 66 & 18.3 \\
\hline Witchcraft & 76 & 21.1 \\
\hline \multicolumn{3}{|l|}{ Types of STIs* } \\
\hline Malaria & 66 & 18.3 \\
\hline Gonorrhoea & 255 & 70.8 \\
\hline Chlamydia & 162 & 45.0 \\
\hline Diarrhoea & 86 & 23.9 \\
\hline Herpes simplex virus & 150 & 41.7 \\
\hline Sickle cell disease & 96 & 26.7 \\
\hline Human papilloma virus & 161 & 44.7 \\
\hline Hepatitis $B$ virus & 139 & 38.6 \\
\hline Syphilis & 252 & 70.0 \\
\hline HIV/AIDS & 309 & 85.8 \\
\hline Tuberculosis & 84 & 25.4 \\
\hline Trichomoniasis & 80 & 22.2 \\
\hline \multicolumn{3}{|l|}{ STIs affect both men and women } \\
\hline Yes & 352 & 97.8 \\
\hline No & 8 & 2.2 \\
\hline \multicolumn{3}{|l|}{ Transmission of STI* } \\
\hline Sharing clothes & 272 & 75.6 \\
\hline Sharing needles & 197 & 54.7 \\
\hline Unprotected sexual intercourse & 348 & 96.7 \\
\hline Mother to child & 169 & 46.9 \\
\hline Kissing & 123 & 34.2 \\
\hline Blood transfusion & 223 & 61.9 \\
\hline
\end{tabular}


infertility $(74.4 \%)$ was the most known complication of STI identified by the respondents. In addition, most (64.7\%) of the respondents knew that not all STIs can be cured, while majority of the respondents (92.2\%) agreed that STIs are preventable. Overall, about three-quarter $(66 \%)$ of the respondents had good knowledge of STIs (Table 3).

TABLE 3: Respondents' knowledge of symptoms and complications of sexually transmitted infections.

\begin{tabular}{|c|c|c|}
\hline Variable & Frequency & $\%$ \\
\hline \multicolumn{3}{|l|}{ STIs can be asymptomatic } \\
\hline Yes & 209 & 58.1 \\
\hline No & 151 & 41.9 \\
\hline \multicolumn{3}{|l|}{ Symptoms of STIs* } \\
\hline Chest pain & 271 & 75.3 \\
\hline Vaginal discharge & 297 & 82.5 \\
\hline Weight loss & 105 & 29.2 \\
\hline Penile discharge & 255 & 70.8 \\
\hline Genital itching & 286 & 79.4 \\
\hline Stomach pain & 169 & 46.9 \\
\hline Pain during urination & 303 & 84.2 \\
\hline Swelling around the genitals & 284 & 78.9 \\
\hline Headache & 233 & 64.7 \\
\hline Blood in urine & 232 & 64.4 \\
\hline \multicolumn{3}{|l|}{ Complications of STIs* } \\
\hline Infertility & 268 & 74.4 \\
\hline Ectopic pregnancy & 137 & 38.1 \\
\hline Miscarriage & 208 & 57.8 \\
\hline Cervical cancer & 213 & 59.2 \\
\hline Testicular cancer & 190 & 52.8 \\
\hline Pelvic inflammatory disease & 238 & 66.1 \\
\hline Premature birth & 129 & 35.8 \\
\hline \multicolumn{3}{|l|}{ All STIs can be cured } \\
\hline Yes & 127 & 35.3 \\
\hline No & 233 & 64.7 \\
\hline \multicolumn{3}{|l|}{ All STIs can be prevented } \\
\hline Yes & 332 & 92.2 \\
\hline No & 28 & 7.8 \\
\hline \multicolumn{3}{|c|}{ Respondents overall knowledge of STI } \\
\hline Good knowledge & 236 & 65.6 \\
\hline Poor knowledge & 124 & 34.4 \\
\hline
\end{tabular}

*, denotes multiple response to the question.

STI, sexually transmitted infections.

\section{Attitude of respondents towards sexually transmitted infection prevention}

Table 4 shows that almost all (95.2\%) of the respondents were in favour of educating young people on STI in academic institutions, while the majority (83.3\%) agreed that people with STIs should not be isolated. A higher percentage $(91.6 \%)$ of the respondents agreed with the idea of using condoms during sexual intercourse to prevent STI, while $94.2 \%$ believed that screening for STI is good, and majority of the respondents (95.2\%) agreed that it was proper to contact the health personnel if one noticed STI symptoms. A large number $(74.8 \%)$ of respondents agreed that watching pornography can contribute to risky sexual practices that can lead to STI. Overall, majority of the respondents $(99 \%)$ had a positive attitude towards the prevention of STIs (Table 5).

\section{Respondents' preventive practices against sexually transmitted infections}

Table 6 shows that about a quarter (24.9\%) of the respondents were sexually active and more than half (59.4\%) of them had sexual debut between the ages of 15 and 19 years. The use of condoms $(94.3 \%)$, abstinence $(86.8 \%)$, being faithful to one partner (73.6\%) and regular screening (67.9\%) were identified as protective measures against STIs. However, less than half $(34.9 \%)$ of the respondents knew that some STIs can also be prevented by vaccination. Some others $(35.9 \%)$ were of the opinion that contraceptive use, having sexual intercourse while standing (18.9\%), taking drugs before sex $(25.5 \%)$ and taking alcohol before sex (17.9\%) could prevent STIs.

A large number (79.3\%) of the respondents used condoms, and more than half $(69.0 \%)$ used it always during sexual intercourse. About half (53.8\%) of the respondents had one partner, while $49.1 \%$ and $95.3 \%$ have never been vaccinated for hepatitis B and human papilloma virus, respectively.

TABLE 4: Respondents' attitude towards prevention of sexually transmitted infections $(n=360)$

\begin{tabular}{|c|c|c|c|c|c|c|c|c|c|c|}
\hline \multirow[t]{2}{*}{ Statement } & \multicolumn{2}{|c|}{ SA } & \multicolumn{2}{|c|}{ A } & \multicolumn{2}{|c|}{1} & \multicolumn{2}{|c|}{ D } & \multicolumn{2}{|c|}{ SD } \\
\hline & Frequency & $\%$ & Frequency & $\%$ & Frequency & $\%$ & Frequency & $\%$ & Frequency & $\%$ \\
\hline $\begin{array}{l}\text { Young people should be educated on } \\
\text { STI in academic institutions }\end{array}$ & 300 & 83.3 & 43 & 11.9 & 16 & 4.4 & 0 & 0 & 1 & 0.3 \\
\hline $\begin{array}{l}\text { People with STI should not be isolated } \\
\text { and avoided }\end{array}$ & 202 & 56.1 & 98 & 27.2 & 29 & 8.1 & 23 & 6.4 & 8 & 2.2 \\
\hline $\begin{array}{l}\text { Condoms should be used during sexual } \\
\text { intercourse to avoid STI }\end{array}$ & 264 & 73.3 & 66 & 18.3 & 26 & 7.2 & 2 & 0.6 & 2 & 0.6 \\
\hline Screening for STIs is good & 262 & 72.8 & 77 & 21.4 & 17 & 4.7 & 3 & 0.8 & 1 & 0.3 \\
\hline $\begin{array}{l}\text { If unsure on symptoms of STI, a health } \\
\text { personnel should be contacted }\end{array}$ & 269 & 75.1 & 72 & 20.1 & 13 & 3.6 & 4 & 1.1 & 0 & 0.0 \\
\hline Young adults with STI must get treated & 280 & 77.8 & 69 & 19.2 & 8 & 2.2 & 3 & 0.8 & 0 & 0.0 \\
\hline $\begin{array}{l}\text { I would advise my partner to seek } \\
\text { treatment if STI symptoms are noticed }\end{array}$ & 298 & 83.0 & 49 & 13.7 & 7 & 2.0 & 4 & 1.1 & 1 & 0.30 \\
\hline $\begin{array}{l}\text { Multiple sexual partners play a role in } \\
\text { the transmission of STDs }\end{array}$ & 265 & 73.6 & 46 & 12.8 & 37 & 10.3 & 8 & 2.2 & 4 & 1.1 \\
\hline $\begin{array}{l}\text { The use of emergency contraceptive pills } \\
\text { does not protect against STI }\end{array}$ & 216 & 60.0 & 75 & 20.8 & 41 & 11.4 & 22 & 6.1 & 6 & 1.7 \\
\hline
\end{tabular}

STI, sexually transmitted infections; SA, strongly agree; A, agree; I, indifferent; D, disagree; SD, strongly disagree. 
TABLE 5: Respondents' overall attitude towards the prevention of sexually transmitted infections.

\begin{tabular}{lcc}
\hline Attitude & Frequency $(\boldsymbol{n}=\mathbf{3 6 0})$ & $\mathbf{\%}$ \\
\hline Positive & 355 & 98.6 \\
Negative & 5 & 1.4 \\
\hline
\end{tabular}

TABLE 6: Respondents' preventive practices against sexually transmitted infections.

\begin{tabular}{|c|c|c|}
\hline Variable & Frequency & $\%$ \\
\hline \multicolumn{3}{|l|}{ Sexually active $(n=425)$} \\
\hline Yes & 106 & 24.9 \\
\hline No & 319 & 75.1 \\
\hline \multicolumn{3}{|c|}{ Age at sexual debut (years) $(n=106)$} \\
\hline $10-14$ & 11 & 10.4 \\
\hline $15-19$ & 63 & 59.4 \\
\hline $20-24$ & 32 & 30.2 \\
\hline \multicolumn{3}{|c|}{ Known protective measures against STI among respondents* } \\
\hline Abstinence & 92 & 86.8 \\
\hline Use of condoms & 100 & 94.3 \\
\hline Faithful to one sexual partner & 78 & 73.6 \\
\hline Regular screening & 72 & 67.9 \\
\hline Contraceptive use & 38 & 35.9 \\
\hline Having sex while standing & 20 & 18.9 \\
\hline Vaccination & 37 & 34.9 \\
\hline Taking drugs before sex & 27 & 25.5 \\
\hline Taking alcohol before sex & 19 & 17.9 \\
\hline \multicolumn{3}{|c|}{ Use of condoms during sexual intercourse among respondent } \\
\hline Yes & 84 & 79.3 \\
\hline No & 22 & 20.8 \\
\hline \multicolumn{3}{|c|}{ Frequency of condoms use $(n=84)$} \\
\hline At every intercourse (always) & 58 & 69.0 \\
\hline Often & 14 & 16.7 \\
\hline Rarely & 12 & 14.3 \\
\hline \multicolumn{3}{|l|}{ Number of sexual partners } \\
\hline 1 & 57 & 53.8 \\
\hline $2-4$ & 39 & 36.8 \\
\hline $5-8$ & 10 & 9.4 \\
\hline \multicolumn{3}{|l|}{ Vaccination: Hepatitis B } \\
\hline Yes & 54 & 50.9 \\
\hline No & 52 & 49.1 \\
\hline \multicolumn{3}{|c|}{ Vaccination: Human papilloma virus } \\
\hline Yes & 5 & 4.7 \\
\hline No & 101 & 95.3 \\
\hline \multicolumn{3}{|c|}{ Overall preventive practice against sexually transmitted infections } \\
\hline Good & 36 & 34.0 \\
\hline Poor & 70 & 66.0 \\
\hline
\end{tabular}

Age, level of education, attitude and preventive practices were all found to be statistically significantly associated with the knowledge of respondents about STIs $(p<0.05)$.

\section{Discussion}

Sexually transmitted infections are among the world's most common diseases, with an annual incidence exceeded only by diarrhoeal diseases, malaria and lower respiratory infections. Each day, almost one million people acquire a new STI; more than 340 million new cases of curable STIs and even more new viral (non-curable) infections occur each year worldwide. Up to $80 \%$ of curable STIs occur in developing countries of the world, with adolescents and young adults having the highest rates of these diseases. In developing countries like Nigeria, STIs are among the leading causes of disability adjusted life years (DALYs) lost for women of reproductive age, exceeded only by maternal causes and HIV. ${ }^{1,2,17,18}$

In this study, 450 young unmarried persons were assessed for knowledge of, attitude towards and preventive practices of STI. The mean age of the respondents was $19.9 \pm 2.5$ years and most $(64.0 \%)$ had tertiary education, which is in line with similar studies carried out in Shone Town Ethiopia $(18.6 \pm 1.9)$ and Malaysia, where majority $(78.3 \%)$ were undergraduates. ${ }^{13,15}$ This study is however contrary carried out in southwest Nigeria, which reported a lower mean age. ${ }^{14}$ This difference is likely because of age difference in the study population.

Most (66\%) of the respondents had overall good knowledge of STIs contrary to a study in Ado-Ekiti, Nigeria, which reported only $6.9 \%$ of the respondents as having overall good knowledge of STIs. ${ }^{14}$ This finding could be because of the fact that most of the respondents in this study were undergraduates, compared to the Ado-Ekiti study, which was carried out among secondary school students. Human immunodeficiency virus or AIDS, gonorrhoea and syphilis were the major types of STIs identified by respondents in this study, which is in line with the finding of similar studies conducted within and outside Nigeria. 12,15,19,20,21

Majority of the respondents in this study knew that unprotected sexual intercourse was a major means of transmission of STIs, while less than half knew about transmission of STIs via mother to child - this finding is consistent with the reports of various other studies conducted within and outside the country. $12,13,14,19$

A statistically significant association was found between age and level of education with knowledge of respondents about STIs $(p<0.05)$, which implies that as the respondents got older or attained a higher level of education, their knowledge also increases. For example, respondents in the age group 20-24 years and those in tertiary institutions had better knowledge of STIs. This finding is similar to that reported by a Malaysian study where students in the age group of 24-30 years were more likely to have good knowledge about STIs, compared to those aged 17-23 years, ${ }^{15}$ which is slightly different from a study conducted in Kwara State, Nigeria, where age was not found to be statistically significant with knowledge, but class do.22

With regard to attitude, almost all respondents in this study were of the view that 'young people should be educated about STI in academic institutions' - this finding is comparable to that of an Indian study. ${ }^{23}$ Condom use during sexual intercourse to avoid STIs was supported by most of the respondents in this study, which is similar to the finding in the Malaysian study..$^{15}$ The majority of the respondents in this study agreed that multiple sexual partners played a major role in the transmission of STIs,' while a high 
TABLE 7: Association of age, sex, attitude and preventive practices of respondents with knowledge of sexually transmitted infections.

\begin{tabular}{|c|c|c|c|c|c|c|c|c|c|}
\hline \multirow[t]{3}{*}{ Socio-demographics } & \multicolumn{9}{|c|}{ Knowledge grade } \\
\hline & \multicolumn{2}{|c|}{ Poor } & \multicolumn{2}{|c|}{ Good } & \multicolumn{2}{|c|}{ Total } & \multicolumn{3}{|c|}{ Statistical test } \\
\hline & $n$ & $\%$ & $n$ & $\%$ & $n$ & $\%$ & $\chi^{2}$ & df & $p$ \\
\hline Age (in years) & & & & & & & 9.991 & 1 & 0.002 \\
\hline $15-19$ & 65 & 43.9 & 83 & 56.1 & 148 & 100 & & & \\
\hline $20-24$ & 59 & 27.8 & 153 & 72.2 & 212 & 100 & & & \\
\hline Level of education & & & & & & & $17.308 \dagger$ & 3 & 0.001 \\
\hline No formal & 1 & 100 & 0 & 0 & 1 & 100 & & & \\
\hline Primary & 2 & 28.6 & 5 & 71.4 & 7 & 100 & & & \\
\hline Secondary & 58 & 48.3 & 62 & 51.7 & 120 & 100 & & & \\
\hline Tertiary & 63 & 27.2 & 169 & 72.8 & 232 & 100 & & & \\
\hline Attitude of respondents & & & & & & & 9.650 & 1 & 0.002 \\
\hline Positive & 119 & 96.0 & 5 & 4.0 & 124 & 100 & & & \\
\hline Negative & 236 & 100.0 & 0 & 0.0 & 236 & 100 & & & \\
\hline Preventive practices of respondents & & & & & & & 7.271 & 1 & 0.007 \\
\hline Good & 30 & 83.3 & 6 & 16.7 & 36 & 100 & & & \\
\hline Poor & 40 & 57.1 & 30 & 42.9 & 70 & 100 & & & \\
\hline
\end{tabular}

$\dagger$, denotes Fisher's exact.

$\chi^{2}$, chi-square value; df, degree of freedom; $p$, level of significance value.

percentage of the participants opposed watching pornography. Similarly, other studies in Malaysia, China and Kampala reported that a higher percentage of the respondents knew that having multiple sexual partners was unsafe. . $^{15,24,25}$ Overall, almost all respondents in this study had a positive attitude towards prevention of STIs, as was the case with that was conducted in Shone Town, Ethiopia13 This study found a statistically significant connection between knowledge and attitude of the respondents $(p<0.05)$. This implies that as the knowledge of the respondents on STIs increases, they show better attitudes towards its prevention.

About a quarter of the respondents in this study were sexually active during the time of this study; this is in line with the finding in a study in Ogbomoso, Nigeria, and Malaysia. ${ }^{5,15}$ More than half $(59.4 \%)$ of the respondents in this study had sexual debut between the ages of 15 and 19 years. This finding is similar to that of a study conducted in Ikeji-Arakeji, Osun State, southwestern Nigeria, which reported mean age at first sexual intercourse as 16.8 years (approximately 17 years). ${ }^{26}$ The study in Ogbomoso, Nigeria, found that mean age at sexual debut was 15.80 years in girls and 15.40 years in boys. ${ }^{5}$ Early sexual debut has been reported to be associated with an increased risk of STIs. Researches have shown that the probability of giving birth during the teen years is three times higher for those who had their sexual debut before the age of 16, compared to those who did not. ${ }^{5}$ This report has shown that about $20 \%$ of women in Nigeria in 2013 were sexually active by the age of 15 years, and the median age for first sex stood at 17.7 years for women and 20.6 years for men. This declining age of first sexual intercourse has been proffered as one possible explanation for the increase in the number of STIs. ${ }^{27,28}$

Some common misconceptions found among the respondents in this study about the prevention of STIs were: about $36 \%$ and $25 \%$ felt that contraceptive use and taking drugs before sex, respectively, are known protective measures against STIs, while alcohol intake before sexual intercourse was also regarded as a prevention method by about $18 \%$ of the respondents. In a study conducted in China, some of the respondents reported that taking antibiotics before or after sex, taking a shower before or after sex or using a sex detergent wash before or after sex could prevent STIs. ${ }^{24}$

About half of the respondents in this study had one regular partner and the majority used condoms, and most of them used it always (at every sexual intercourse). This finding is contrary to the report of a study among youths in Nairobi where less than half of the respondents use condoms and in southern Ethiopia where $29.0 \%$ use condoms and $11.9 \%$, respectively, use it always. ${ }^{29,30}$ These differences probably could be because of differences in the cultures and religious beliefs in the different study settings. The study in Malaysia reported that about two-third of the respondents had only one partner. ${ }^{15}$ These findings point to a higher rate of risky sexual behaviours among young unmarried people in the different study settings. About half (51\%) of the respondents in this study have been vaccinated against hepatitis B virus, while almost all (95\%) were not protected against human papilloma virus. Pre-exposure vaccination has been recommended as one of the most effective methods for preventing transmission of human papillomavirus (HPV), hepatitis A virus (HAV) and hepatitis B virus (HBV). Human papillomavirus vaccination is recommended routinely for boys and girls aged 11 or 12 years beginning at 9 years of age. ${ }^{31}$

Overall, about two-third (66.0\%) of the respondents in this study had poor preventive practices against STIs. Knowledge of respondents of STIs was found to be statistically significant with the preventive practices of STIs $(p<0.05)$.

\section{Conclusion}

Most of the respondents in this study were aware of and had good attitude towards the prevention of STI, but gaps still exist in their knowledge of STIs. Preventive practices of STIs are very poor among the respondents. 
Therefore, targeted education on behaviour change communication aimed at young unmarried persons in communities is highly recommended to improve their knowledge and thereby implementation of preventive practices against STIs.

\section{Limitations}

This study had some limitations. Firstly, our study participants were from only one LGA out of the 20 in Lagos State. This study was conducted in a community, and the results represent the views of the respondents in that community alone, which might be different from others in other parts of the state. The presence of recall bias in this study is also very likely. Therefore, further research with a larger population with adequate power and sample sizes is recommended.

\section{Acknowledgements}

The authors thank the respondents for being part of the study and the research assistants for collection of the data.

\section{Competing interests}

The authors have declared that no competing interests exist.

\section{Authors' contributions}

O.E.O. was responsible for the concept, design, drafting, data analysis and manuscript revision, while O.D.O. was responsible for data collection, data analysis and manuscript writing. D.O. participated in design and manuscript review, and O.G.E. was responsible for editing and manuscript review. All the authors approved the final version of the manuscript.

\section{Funding information}

This research received no specific grant from any funding agency in the public, commercial or not-for-profit sectors.

\section{Data availability statement}

Data sharing is not applicable to this article as no new data were created or analysed in this study.

\section{Disclaimer}

The views and opinions expressed in this article are those of the authors and do not necessarily reflect the official policy or position of any affiliated agency of the authors.

\section{References}

1. World Health Organization. Sexually transmitted infections (STIs) [homepage on the Internet]. 2016 [cited 2018 May 07] Available from: http://www.who.int/ mediacentre/factsheets/fs110/en/

2. World Health Organization. Global strategy for the prevention and control of sexually transmitted infections: 2006-2015: Breaking the chain of transmission. Geneva: World Health Organization; 2006.

3. United Nations, Educational, Scientific and Cultural Organization (UNESCO). Learning to live together. What do we mean by youth? [homepage on the Internet]. [cited 2018 May 12]. Available from: www.unesco.org/new/en/socialand-human-sciences/themes/youth/youth-definition
4. Centers of Disease Control and Prevention. Sexually transmitted diseases. CDC Fact Sheet: Information for teens and young adults: staying Healthy and Preventing STDs [homepage on the Internet]. [cited 2018 May 14]. Available from: https://www.cdc.gov/std/life-stages-populations/stdfact-teens.htm

5. Fehintola FO, Fehintola AO, Ogunlaja OA, et al. Prevalence and predictors of early sexual debut among adolescents in Ogbomoso, Nigeria. Am J Public Health Res. 2018;6(3):148-154. https://doi.org/10.12691/ajphr-6-3-4

6. National Population Commission (NPC) Nigeria and ICF Macro. Nigeria demographic and health survey 2008. Abuja: National Population Commission and ICF Macro, 2009; p. 225-238.

7. Omobude-Idiado SN, Bazuaye GN. Patterns of sexually transmitted infections (STIs) reported among students in a federal university in Midwestern Nigeria. Coll (STIs) reported among students
Stud J. 2009;43(2):384-390.

8. Shelton JD, Halperin DT, Nantulya V, Potts M, Gayle HD, Holmes KK. Partner reduction is crucial for balanced 'ABC' approach to HIV prevention [serial online]. BMJ. 2004 [cited 2018 May 14]. Available from: https://www.ncbi.nlm.nih.gov/m/ pubmed/15073076/

9. Surulere LGA in Lagos State [homepage on the Internet]. [cited 2019 July 05] Available from: https://www.citypopulation.de/php/nigeria-admin.php?adm2id= NGA025020

10. Lagos State Government. Surulere [homepage on the Internet]. [cited 2018 Jun 03]. Available from: http://www.lagosstate.gov.ng/entities.php?k=109

11. Surulere Local Government Area in Nigeria. City population [homepage on the Internet]. [cited 2018 Sep 07]. Available from: citypopulation.de

12. Chindinma N, Ekenechukwu Y, Birinus E, Christian O, Ikenna O. HIV and sexually transmitted infections knowledge and practices; a survey of female secondary school students in Enugu, South East Nigeria. J Med Res. 2017;3(2):66-70. https:// doi.org/10.31254/jmr.2017.3208

13. Kejela G, Soboka B. Assessment of knowledge, attitude and preventive practice towards sexually transmitted infections among preparatory school students in Shone Town, Ethiopia 2014. J Health Med Inform. 2015;6:183. https://doi. org/10.4172/2157-7420.1000183

14. Amu EO, Adegun PT. Awareness and knowledge of sexually transmitted infections among secondary school adolescents in Ado Ekiti, South Western Nigeria. J Sex Trans Dis. 2015;2015:1-7. https://doi.org/10.1155/2015/260126

15. Folasayo AT, Oluwasegun AJ, Samsudin S, Saudi SN, Osman M, Hamat RA. Assessing the knowledge level, attitudes, risky behaviors and preventive practices on sexually transmitted diseases among university students as future healthcare providers in the central zone of Malaysia: A cross sectional study. Int J Environ Res Public Health. 2017;14(2):159. https://doi.org/10.3390/ijerph14020159

16. Makwe $E$, Adenyuma MO. Awareness of sexually transmitted infections (STIs) including HIV/AIDS among undergraduates' students of university of Abuja Nigeria. BrJ Appl Sci Technol. 2014;4(4):705-717. https://doi.org/10.9734/BJAST/2014/6102

17. Sexually transmitted infections in developing countries: Current concepts and strategies on improving STI prevention, treatment, and control. In: CDC 2005 STD treatment guidelines [homepage on the Internet]. [cited 2019 July 05]. Available from: http://www.cdc.gov/std/treatment/

18. World Health Organization. Global strategy for the prevention and control of sexually transmitted infections: 2006-2015. Breaking the chain of transmission; who. int. 2007; p. 61.

19. Ash FK, Kaya S, Husrev D, Evren H. Knowledge, attitudes and behavior towards sexually transmitted diseases in Turkish Cypriot. Cent Eur J Public Health. 2013;21(1):54-58. https://doi.org/10.21101/cejph.a3808

20. Norbu K, Mukhia S, Tshokey. Assessment of knowledge on sexually transmitted infections and sexual risk behavior in two rural districts of Bhutan. BMC Public Health. 2013;13:1142. https://doi.org/10.1186/1471-2458-13-1142

21. Santos-Hovener C, Marcus U, Koschollek C, et al. Determinants of HIV viral hepatitis and STI prevention needs among African migrants in Germany; a cross-
sectional survey on knowledge, attitudes, behaviors and practices. BMC Public sectional survey on knowledge, attitudes, behaviors and practices.
Health. 2015;15:753. https://doi.org/10.1186/s12889-015-2098-2

22. Oluyemi JA, Yinusa MA, Abdullateef R, Akoh S, Kehinde K. Knowledge of sexually transmitted diseases among secondary school adolescents in Asa local government area of Kwara State Nigeria. African Sociological Review. 2015; 19 (1): 64-76.

23. Nagesh TS, Akhilesh A. knowledge and attitude about sexually transmitted infections other than HIV among college students. Indian J Sex Transm Dis AIDS. 2017;38(1):10-14. https://doi.org/10.4103/0253-7184.196888

24. Zhang D, Pan H, Cui B, Law F, Farrar J, Ba-Thein W. Sexual behaviors and awareness of sexually transmitted infections among Chinese university students. J Infect Dev Ctries. 2013;7(12):966-974. https://doi.org/10.3855/jidc.3872

25. Sekirime WK, Tamale J, Lule JC, Wabwire-Mangen F. Knowledge, attitude and practice about sexually transmitted diseases among university students in Kampala. Afr Health Sci. 2001;1(1):16-22.

26. Akokuwebe ME, Daini B, Falayi EO, Oyebade O. Knowledge and attitude of sexually transmitted diseases among adolescents in Ikeji-Arakeji, Osun State, in SouthWestern Nigeria. Afr J Med Med Sci. 2016;45(3):281-289.

27. National Population Commission (NPC) [Nigeria] and ICF International. Nigeria demographic and health survey 2013. Abuja: NPC and ICF International; 2014.

28. Adler MW. Sexually transmitted infections in Europe. Eurohealth. 2006;12:3-6.

29. Nega DM, Sindew MA, Befikadu TG, Girum ST, Zeleke AM, Eshetu ZT. Knowledge, attitude and preventive practices towards sexually transmitted infection among preparatory school students of Arsi Negelle Town. J AIDS Clin Res. 2017:8(12):748. https://doi.org/10.4172/2155-6113.1000748

30. Wairimu HW. Knowledge, attitudes and practices concerning, HIV/AIDS prevention among youth in East Leigh location in Nairobi County. Research project submitted for the Award of Masters of Arts in Sociology. University of Nairobi., 2014

31. Workowski KA, Gail A. Bolan GA. Sexually transmitted diseases treatment guidelines. MMWR Recomm Rep. 2015;64(RR-03):1-137. 